\title{
Is 'Clinical Inertia' Blaming Without Under- standing? Are Competing Demands Excuses?
}

\author{
Kurt C. Stange, $M D, P b D$, Editor \\ Ann Fam Med 2007;5:371-374. DOI: 10.1370/afm.734
}

\section{COMPETING DEMANDS OR CLINICAL INERTIA?}

The online discussion of a study of competing demands in diabetes treatment in the last issue of Annals epitomizes 2 critical, polarizing questions. ${ }^{1}$ These questions pit a fundamental feature of primary care against efforts to improve quality of care:

- Is the failure to aggressively advance care along evidence-based guidelines (termed clinical inertia) ${ }^{2,3}$ a failure of medical practice?

- Is balancing multiple problems, including those not guided by evidence-based guidelines (termed competing demands ${ }^{4}$ or competing opportunities) ${ }_{1}^{5,6}$ a fundamental feature of the added value of primary care? ${ }^{7}$

This debate among the study author, ${ }^{1}$ the initial proponent of the concept of clinical inertia, ${ }^{2}$ and other practicing clinicians is vital reading for those who want to be sure that efforts to improve care do not inadvertently damage care. ${ }^{8}$ At the heart of this debate is another question: In prioritizing care, whose agenda comes first: the clinicians' evidence-based plan or the patients' concerns?

The originator of the clinical inertia explanation for disease-specific underperformance contends:

We all have symptomatic complaints-the issue is priority. When patients see me, I review their meds, review status of blood pressure/cholesterol/use of aspirin/diabetes/osteoporosis/cancer screening next, make changes in management as appropriate, ask about chest pain/pressure, shortness of breath, GI upset, dizziness, and ankle swelling, THEN inquire about other issues.

In my view, Parchman et al have advanced the field by showing as specifically as possible that providers may elect to respond to patients' complaints rather than tightening up management of their asymptomatic chronic disorders. This is indeed clinical inertia. ${ }^{9}$

The evidence for benefit of good glycemic control in type 2 diabetes is strong. What I think is more of a problem is education of physicians as to how to monitor their own performance. $^{10}$
Some of apparent clinical inertia is an active decision (limited life expectancy, etc) but most is probably more passive (didn't get around to it, etc-which might be due in part to competing demands and/or feeling that the asymptomatic problem generally is of low priority.) But the choice is largely the provider's. ${ }^{11}$

Clinical inertia implies that a change in therapy is clinically indicated...it's important to know whether failure to intensify therapy was an active decision-or whether diabetes wasn't on the table at all. ${ }^{12}$

Moreover, a dominant problem seems to have been time, more than concerns.... More broadly, the issue might be whose concerns are allowed to dominate.... A provider can and should lead in deciding whether to use time for dealing with symptomatic complaints vs. modifying treatment of asymptomatic blood pressure, cholesterol, and glucose problems-major causes of morbidity and mortality in the United States. And if the providers elect to deal only with the symptomatic complaints, isn't that clinical inertia? ${ }^{9}$

The author of the study on competing demands vs clinical inertia argues:

The use of the term "clinical inertia," as coined by Dr Phillips and colleagues, leads to the assumptions reflected in their as yet unproven hypotheses ... about the cause of the phenomenon: 1) use of "soft" reasons to delay a change in treatment $; 2$ ) overestimation of the quality of care provided; 3) lack of knowledge about appropriate goals for therapy.

One might argue that by addressing patient concerns, primary care clinicians are working to gain patient trust. Trust in the physician has been shown to be a significant predictor of patient adherence to medication regimens. Thus, by allowing patient concerns to be a high priority, intensification of treatment for poorly controlled diabetes is adhered to.

So while Dr Phillips insists that "clinical inertia" on the part of the physician is the central issue, evidence to date supports the conclusion that approaches to overcome competing demands that are multifaceted and occur at the level of the practice are more effective strategies to improve outcomes for our patients with diabetes than merely focusing on changing physician behavior. ${ }^{13}$ 
Other readers express concern that the label "clinical inertia" does not adequately capture the complexity of the primary care clinical encounter, and may have unintended consequences.

Hankey notes:

A positive decision NOT to change a medication at the current encounter is not merely "clinical inertia.".. The actual average number of problems dealt with per visit for a diabetic patient is $4.6 \ldots$. This supercharged [physician cognitive] activity could hardly be classified as "inertia."

As the article demonstrates, family physicians actually do shorten up the time interval until the next visit if we see an $A_{1 C}$ too high and can't deal with it today. We bring the patient back sooner if we have several concurrent problems to address. We understand that we can't assimilate too many changes into the patient's daily life all at once.

This article by Parchman shows that when we veer from "the checklist" and appear to neglect check-marks, we are not just inert lumps doing nothing, but rather we are actively interacting, prioritizing, balancing, and planning on the patient's behalf. The integrative parts of our brains are working in high gear. We must use the new evidence provided in this article to create a rational "care evaluation" system, which takes patient concerns, comorbidities, system complexity and other competing demands into consideration. ${ }^{14}$

Physicians take care of patients-not checkmarks on a to-do list of care management chores....

But family physicians are in conflict. Often our bonuses and even our basic compensation depend on the checkmarks which intrude upon our visits... Many of us fall into the trap of considering all of [these care initiatives] before we bother to ask, "How can I help you today?"

If the patient and physician together decide that the priorities at this visit promote the patient's depression, her alcohol problem and a new, itchy rash to a higher rung than an $\mathrm{A}_{1 \mathrm{C}}$ of $7.2 \%$, then those problems can be aggressively attacked. If we dare to consciously drop the $\mathrm{A}_{1 \mathrm{C}}$ on our priority list, our statistics will suffer, but the patient will receive better care

This Parchman article points out very well that good primary care physicians recognize these difficulties and have adopted strategies to compensate. They plan ahead to future visits. There is no emergency room pressure to do it all at one visit. ${ }^{15}$

Other clinician readers further the discussion. Spann states:

To imply that primary care physicians don't change medications in diabetic patients whose $\mathrm{HbA}_{1 \mathrm{C}}$ levels are higher than target because of clinical inertia ignores the complexity of primary care practice and the reality of multiple competing demands, as well as the importance of considering the patient's own goals and preferences for care. ${ }^{16}$

Bayliss adds:

Patients who do not feel that their primary concerns are addressed (if not necessarily solved) may be less inclined to adhere to other treatment recommendations.
As is often the case, exploration of complex situations reveals parallel processes: in this case, competing demands for both patients and their providers... It will take increased study of the process of care (as compared to the content of care) in order to design solutions. For starters, we might talk to both patients and providers and focus on what they have in common: a need to prioritize concerns for a common goal. One part of this is to emphasize the larger relationship and step out of the office encounter as the primary vehicle for medical recommendations. ${ }^{17}$

\section{Fortin notes:}

Although it is "proven" important to reach target levels in the long run, it may be worth waiting till the next appointment if other concerns have been judged a priority. ... not responding to the patient's complaints may constitute clinical inertia. ${ }^{18}$

Steinberg concludes that "inertia and distraction is probably a good thing. ${ }^{19}$

\section{Wexler balances both perspectives in stating:}

Competing demands are a significant patient-related factor in reaching a desired treatment goal. However, physician factors, as suggested by clinical inertia, also have an impact, and should not be discounted. ${ }^{20}$

Both sides of this argument have a point, and much of the polarization of the argument comes from not having the sufficiently nuanced and individualized data called for by Bayliss. ${ }^{17}$ The bottom line is that as clinicians, we do need knowledge of disease-specific evidence-based management, as well as systems of care, to support this management, and sufficient selfawareness to know when we are being distracted by trivialities. Following disease-specific guidelines is not even close to the whole story, however. Efforts to characterize the failure to aggressively advance care along evidence-based guidelines, without acknowledging the beautiful complexity of care focused on the person (rather than just disease), risk doing more harm than good. Primary care, as Hankey points out, involves the integration of care of the whole person-optimizing not only multiple problems ${ }^{21}$ but multiple perspectives. As crystallized by Thomas, ${ }^{22}$ this recognition involves a world view that is vital to name and understand, lest it be trivialized. Patients are best served when their expert knowledge of their concerns, hopes, and selves are assimilated with the clinician's knowledge of what health care has to offer to improve their short- and long-term health and function. This negotiation is most likely to be achieved if both parties are self-aware and have an ongoing relationship.

The clinical inertia perspective reminds us to keep in mind the long-term benefits of less-immediate health care, such as chronic disease management or prevention, which easily can be put on the back 
burner by both clinicians and patients. The competing demands perspective reminds us to value the fundamental prioritizing, relationship-centered functions of primary care ${ }^{5}$ that are not recognized, and therefore potentially undermined, by most current efforts to improve quality.

Online discussion of other articles in the last issue of Annals contributed relevant perspectives to this debate. Barrett and colleagues developed and used a method for determining which treatments are sufficiently effective, from the patient's point of view, to be justified, compared with their downsides. ${ }^{23}$ Their study stimulated important ideas about how this "sufficiently important difference" can be used to guide diagnosis, treatment, research, and policy ${ }^{24-26}$ by focusing efforts on "those interventions whose efforts are likely to be big enough to be considered worthwhile by a substantial proportion of patients," 24 and to further personalize such interventions on the basis of individual patient values. Relevant to aggressive efforts to overcome clinical inertia, Hahn wonders "whether measurement of sufficiently important difference in physicians and in their patients would yield equivalent results. Or would systematic differences be present? If so, this might be important information to have when confronting the deep (and often unconscious) tendency towards paternalism within the medical profession." ${ }^{26}$

Marvel, in discussing an earlier essay, "Jazz and the Art of Medicine," 27 informs our consideration of inertia vs competing demands. He describes "nuances that distinguish mastery from competence," noting that "elusive interpersonal skills that are subjectively valued by patients may be the distinguishing traits of master clinicians." 28

The essay on an ecosystemic approach to chronic care design and practice ${ }^{29}$ expands understanding of clinical inertia and competing demands by calling for "a communal and dynamic view of the response of the patient, family and health professional to chronic illness. ${ }^{130}$ Calling for "a complete rethinking and reengineering of the healthcare system, [moving] from an 'ethos of standardization and prefabricated structures to a streaming and tracking ethos, ${ }^{\prime \prime \prime} 31$ Fortin emphasizes the need for complex, relational decision making at the point of care.

\section{OTHER THREADS OF DISCUSSION}

Other online discussion helps us to discover additional insights. In response to an article on acanthosis nigricans and diabetes risk factors, ${ }^{32}$ we learn that "acanthosis nigricans is simpler and easier to screen compared with other risk factors for diabetes." ${ }^{133}$

A passionate and well-informed discussion of a study of electronic medical records and diabetes quality of care ${ }^{34}$ concludes that the electronic health record is an important tool for improving care, but magical thinking that it will solve health care quality problems without investment of time and systems thinking risks making things worse. ${ }^{35-40}$

Dr Geyman's analysis of disease management programs ${ }^{41}$ stimulated detailed responses from those in the industry ${ }^{42,43}$ and from those in practice. ${ }^{44-46}$ Not surprisingly, these perspectives differ dramatically.

The essay "Impotence of Being Important"47 stimulated thoughtful reflections on leadership from experienced and articulate leaders. ${ }^{48-50}$

Finally, in response to an earlier online discussion, a pharmacist ${ }^{51}$ calls for an independent drug information service to counteract the biased information being provided to clinicians and patients by manufacturers.

Please join the exchange of ideas at http://www. AnnFamMed.org.

To read or post commentaries in response to this article, see it online at http://www.annfammed.org/cgi/content/full/5/4/371.

\section{References}

1. Parchman ML, Pugh JA, Romero RL, Bowers KW. Competing Demands or Clinical Inertia: The Case of Elevated Glycosylated Hemoglobin. Ann Fam Med. 2007;5(3):196-201.

2. Phillips LS, Branch WT, Book CB, et al. Clinical inertia. Ann Intern Med. 2001;135(9):825-834.

3. Ziemer DC, Miller CD, Rhee MK, et al. Clinical inertia contributes to poor diabetes control in a primary care setting. Diabetes Educ. 2005;31(4):564-571.

4. Jaén CR, Stange KC, Nutting PA. Competing demands of primary care: a model for the delivery of clinical preventive services. J Fam Pract. 1994;38(2):166-171.

5. Stange KC, Jaén CR, Flocke SA, Miller WL, Crabtree BF, Zyzanski SJ. The value of a family physician. J Fam Pract. 1998;46(5):363-368.

6. Jaén CR, Mcllvain H, Pol L, Phillips RL, Jr, Flocke S, Crabtree BF. Tailoring tobacco counseling to the competing demands in the clinical encounter. J Fam Pract. 2001;50(10):859-863.

7. Stange KC. The paradox of the parts and the whole in understanding and improving general practice. Int J Qual Health Care. 2002;14(4):267-268.

8. Stange KC. "One size doesn't fit all." Multimethod research yields new insights into interventions to improve preventive service delivery in family practice. J Fam Pract. 1996;43(4):358-360.

9. Phillips L. Responding only to patient complaints IS clinical inertia [eletter]. http://www.annfammed.org/cgi/eletters/5/3/196\#5762, 5 Jun 2007.

10. Phillips L. Re: responding only to patient complaints IS clinical inertia [eletter]. http://www.annfammed.org/cgi/eletters/5/3/196\#5830, 9 Jun 2007.

11. Phillips L. Re: response to Dr Hicks [eletter]. http://www. annfammed.org/cgi/eletters/5/3/196\#589554, 24 Jun 2007

12. Phillips L. Re: response to Dr Hicks [eletter]. http://www. annfammed.org/cgi/eletters/5/3/196\#5895, 25 Jun 2007.

13. Parchman $M L$, et al. Author's response to Dr Phillips [eletter]. http:// www.annfammed.org/cgi/eletters/5/3/196\#5845, 11 Jun 2007. 
14. Hankey TL. A care evaluation tool must consider competing demands [eletter]. http://www.annfammed.org/cgi/eletters/5/3/196\#5864, 18 Jun 2007.

15. Hankey TL. Treat the patient-NOT the checkmark [eletter]. http:// www.annfammed.org/cgi/eletters/5/3/196\#5888, 22 Jun 2007.

16. Spann SJ. Clinical inertia or competing demands [eletter]?, http:// www.annfammed.org/cgi/eletters/5/3/196\#5840, 11 Jun 2007.

17. Bayliss EA. The parallel process of competing demands [eletter] http://www.annfammed.org/cgi/eletters/5/3/196\#5838, 10 Jun 2007.

18. Fortin M. Competing demands vs. clinical inertia: a question of perspective [eletter]. http://www.annfammed.org/cgi/eletters/5/3/196\#5832, 10 Jun 2007

19. Steinberg JD. Re: Responding only to patient complaints IS clinical inertia [eletter]. http://www.annfammed.org/cgi/eletters/5/3/196\#5810, 8 Jun 2007.

20. Wexler RK. Clinical inertia, competing demands, and hypertension [eletter]. http://www.annfammed.org/cgi/eletters/5/3/196\#5803, 8 Jun 2007.

21. Beasley JW, Hankey TH, Erickson R, et al. How many problems do family physicians manage at each encounter? Ann Fam Med. 2004; 2(5):405-410.

22. Thomas PR. Future challenges for PBRNs [eletter]. http://www. annfammed.org/cgi/eletters/5/3/242\#5882, 21 Jun 2007.

23. Barrett B, Harahan B, Brown D, Zhang Z, Brown R. Sufficiently important difference for common cold: severity reduction. Ann Fam Med. 2007;5(3):216-223.

24. Herbert RD. Benefit-harm trade-off method has important implications [eletter]. http://www.annfammed.org/cgi/eletters/5/3/216\#5860, 16 Jun 2007

25. Barrett B. Reply to Dr Hahn [eletter]. http://www.annfammed.org/ cgi/eletters/5/3/216\#5851, 13 Jun 2007.

26. Hahn DL. The personal sufficiently important difference (pSID): does it have application to clinical research [eletter]? http://www. annfammed.org/cgi/eletters/5/3/216\#5798, 7 Jun 2007.

27. Haidet P. Jazz and the 'art' of medicine: improvisation in the medical encounter. Ann Fam Med. 2007;5(2):164-169.

28. Marvel K. Jazz and the master clinician [eletter]. http://www. annfammed.org/cgi/eletters/5/2/164\#5735, 23 May 2007.

29. Soubhi $H$. Toward an ecosystemic approach to chronic care design and practice in primary care. Ann Fam Med. 2007;5(3):263-269.

30. Hudon C. Empowering ecosystems for chronic care [eletter]. http:// www.annfammed.org/cgi/eletters/5/3/263\#5820, 8 Jun 2007.

31. Fortin M. Chronic care complexity ... [eletter]. http://www. annfammed.org/cgi/eletters/5/3/263\#5814, 7 Jun 2007.

32. Kong AS, Williams RL, Smith $M$, et al. Acanthosis nigricans and diabetes risk factors: prevalence in young persons seen in southwestern US primary care practices. Ann Fam Med. 2007;5(2):202-208.
33. Hirschler V. Acanthosis nigricans and risk factors for type 2 diabetes [eletter]. http://www.annfammed.org/cgi/eletters/5/3/202\#5760, 5 Jun 2007.

34. Crosson JC, Ohman-Strickland PA, Hahn KA, et al. Electronic medical records and diabetes quality of care: results from a sample of family medicine practices. Ann Fam Med. 2007;5(3):209-215.

35. Lett JE, et al. HIT done right improves care [eletter]. http://www. annfammed.org/cgi/eletters/5/3/209\#5913, 29 Jun 2007.

36. Chaudhry BI. Electronic health records: potential and practice [eletter]. http://www.annfammed.org/cgi/eletters/5/3/209\#5875, 20 Jun 2007.

37. Smith SA. EMR and information systems in support of chronic care [eletter]. http://www.annfammed.org/cgi/eletters/5/3/209\#5834, 10 Jun 2007.

38. Andrews ST. EHR bad for quality? Not the author's conclusion [eletter]. http://www.annfammed.org/cgi/eletters/5/3/209\#5828, 8 Jun 2007.

39. Patterson DA. EHR's in the "real world" [eletter]. http://www. annfammed.org/cgi/eletters/5/3/209\#5770, 5 Jun 2007.

40. Andrews ST. Technophile's response [eletter]. http://www. annfammed.org/cgi/eletters/5/3/233\#5788, 5 Jun 2007.

41. Geyman JP. Disease management: panacea, another false hope, or something in between?. Ann Fam Med. 2007;5(3):257-260.

42. Norman G. Disease management: like all health delivery evolutionary change, disease management represents neither panacea nor false hope, but real progress [eletter]. http://www.annfammed.org/ cgi/eletters/5/3/257\#5793, 8 Jun 2007.

43. Popik WC, et al. Alignment of disease management, chronic care model [eletter]. http://www.annfammed.org/cgi/eletters/5/3/257\#5784, 5 Jun 2007

44. Richter D. Disease management in Vermont [eletter]. http://www. annfammed.org/cgi/eletters/5/3/257\#5878, 21 Jun 2007.

45. Sullivan K. Claim that DM saves money is an example of faithbased health policy [eletter]. http://www.annfammed.org/cgi/eletters/5/3/257\#5849, 13 Jun 2007.

46. McCanne DR. Support patients, not administrators [eletter]. http:// www.annfammed.org/cgi/eletters/5/3/257\#5764, 5 Jun 2007.

47. Couper ID. The impotence of being important-reflections on leadership. Ann Fam Med. 2007;5(3):261-262.

48. Thomas PR. Happy feet [eletter]. http://www.annfammed.org/cgi/ eletters/5/3/261\#5880, 21 Jun 2007

49. Schwenk TL. Penguins [eletter]. http://www.annfammed.org/cgi/ eletters/5/3/261\#5822, 8 Jun 2007

50. Rosenthal TC. Impotence avoidance in practice [eletter]. http:// www.annfammed.org/cgi/eletters/5/3/261\#5806, 7 Jun 2007.

51. Moores KG. Fund an independent drug information service [eletter] http://www.annfammed.org/cgi/eletters/5/2/101\#5709, 22 May 2007. 